УДК 343.12

DOI https://doi.org/10.32837/pyuv.v0i1.744

\author{
B. В. Назаров \\ orcid.org/0000-0002-3725-7745 \\ доктор юридичних наук, професор, \\ професор кафедри крилінального процесу та криліналістики \\ Акаделії адвокатури України
}

Т.В. Смалюк

orcid.org/0000-0002-6443-3038

начальник відділу представництва інтересів держави в суді та при виконанні судових рішень Волинської обласної прокуратури

\title{
ОСОБЛИВОСТІ НОРМАТИВНОГО РЕГУЛЮВАННЯ ПРОЦЕСУАЛЬНОГО СТАТУСУ ТРЕТЬОЇ ОСОБИ, ЩОДО МАЙНА ЯКОЇ ВИРІШУЕТЬСЯ ПИТАННЯ ПРО АРЕШТ
}

Постановка проблеми. Одним із найбільш розповсюджених заходів забезпечення кримінального провадження $є$ арешт майна, який залежно від його мети застосовується до визначених у законі учасників кримінального провадження, у тому числі фізичних та юридичних осіб. Завдання арешту майна полягає в запобіганні можливості його відчуження, знищення, приховування від конфіскації чи спеціальної конфіскації. Нині у світовій практиці стійкою тенденцією є заміна загальної конфіскації на спеціальну, оскільки остання не є покаранням, має превентивний характер, спрямована на позбавлення особи доходів (активів), які вона отримала від учиненого злочину, виключення можливості їх використання в подальшій злочинній діяльності. Саме спеціальна конфіскація як захід кримінально-правового характеру зумовила необхідність введення вітчизняним законодавцем у кримінальне провадження такого учасника, як третя особа, щодо майна якої вирішується питання про арешт (ст. $64^{2}$ КПК України).

Водночас чимало питань щодо регламентації арешту майна третьої особи та її процесуального статусу досі не знайшли однозначного вирішення ні в науковій літературі, ні в правозастосовчій практиці, що зумовило необхідність проведення подальших досліджень у цьому напрямі.

Аналіз останніх досліджень i публікацій. В Україні питання становлення та розвитку інституту третьої особи, щодо майна якої вирішується питання про арешт, досліджували Ж.В. Байдак, О.В. Верхогляд-Герасименко , І.В. Гловюк, В.А. Завтур, Я.В. Замкова, О.М. Калачова, Т.В. Корчева, М.В. Лепей, Н.С. Моргун, О.В. Музиченко, Т.О. Музиченко, О.Ю. Татаров, В.М. Трофименко та інші. Водночас сучасний погляд на кримінальне процесуальне законодавство України, вивчення літературних джерел, статистичних матеріалів та судово-слідчої практики вимагає якісно нових підходів до вирішення проблем, що пов'язані з регламентацією процесуального статусу третьої особи, щодо майна якої вирішується питання про арешт.

Мета публікації полягає в дослідженні питань нормативно-правової регламентації інституту третіх осіб, щодо майна яких вирішується питання про арешт, визначенні її процесуального статусу, виявленні в законодавстві прогалин, які потребують свого доктринального аналізу й нормативного врегулювання.

Виклад основного матеріалу. Поява третьої особи, щодо майна якої вирішується питання про арешт, як нового учасника кримінального провадження є одним із важливих нововведень кримінального процесуального законодавства України. Ï̈̈ процесуальний статус регламентується ст. $64^{2}$ КПК України. Відповідно до зазначеної норми, третьою особою, щодо майна якої вирішується питання про арешт, може бути будь-яка фізична або юридична особа. Визначення такого учасника провадження прив'язується законодавцем до моменту звернення прокурора до суду з клопотанням про арешт майна цієї особи.

Загалом можливість накладення арешту на майно третьої особи зумовлена необхідністю реалізації публічно-правової мети кримінального провадження, а саме спеціальної конфіскації. Дослідження цього питання $є$ вкрай важливим, оскільки як серед науковців, так і серед практиків іноді допускаються помилки саме у визначенні третьої особи в кримінальному провадженні, а також мети застосування арешту іï майна. Нариклад, на думку О.В. Верхогляд-Герасименко, арешт на майно третьої особи може бути накладений з метою або збереження речових доказів, або забезпечення спеціальної конфіскації [1, с. 20, 21]. У судовій практиці також трапляються випадки ототожнення особи, на майно якої накладено арешт із метою забезпечення його збереження як речового доказу, з третьою особою, що є не досить правильно. Так, в ухвалі Апеляційного суду Одеської 
області від 30 березня 2016 р. указується на третю особу - власника майна, на автомобіль якого накладено арешт із метою забезпечення його збереження як речового доказу [2]. Слід наголосити, що колегія суддів у всіх вищевказаних випадках фактично прирівнювала власника або володільця майна, на яке накладено арешт із метою забезпечення збереження речових доказів, до третьої особи, існування якої доречне лише в разі вирішення питання про накладення арешту на майно з метою спеціальної конфіскації, однак не для забезпечення збереження речових доказів [3, с. 127]. Зазначене ще раз доводить важливість і складність досліджуваної нами проблематики.

Таким чином, визначаючи мету забезпечення арешту майна третьої особи (п. 2 ч. 2 ст. 170 КПК України), законодавець долучає цього учасника кримінального провадження не в контексті його персональної матеріальної відповідальності за неправомірні дії підозрюваного, обвинуваченого, а лише тому, що в нього перебуває майно, яке підлягає спеціальній конфіскації. Під час реалізації вказаного вище заходу третя особа обмежується у праві власності на своє майно, але не втрачає права на нього до винесення остаточного рішення судом, який і визначає остаточну долю арештованого майна.

Прийняття слідчим, прокурором, слідчим суддею, судом рішення про арешт майна третіх осіб має Ірунтуватися на даних, що вказують на важливість застосування цього арешту у зв'язку 3 наявністю високого ступеня ймовірності приховування, пошкодження, псування, знищення, перетворення, відчуження відповідного майна.

Слово «статус» трактується як правове становище (сукупність прав та обов'язків) фізичної або юридичної особи [4, с. 626]. В.I. Галаган, O.M. Калачова вважають, що для визначення процесуального статусу третьої особи необхідна наявність фактичних та формальних підстав. Фактичні підстави підтверджують певні обставини, що спонукали до набуття особою статусу учасника кримінального провадження, формальні грунтуються на певних діях або рішеннях органів розслідування, у результаті яких особа отримує процесуальний статус. Фактичними підставами визначення процесуального статусу третьої особи, щодо майна якої вирішується питання про арешт, є зібрані під час досудового розслідування достатні докази, що її майно підлягає спеціальній конфіскації. Формальною підставою визначення процесуального статусу третьої особи згідно 3 ч. 2 ст. $64^{2}$ КПК є звернення прокурора до суду 3 клопотанням про арешт їі майна. Клопотання складається відповідно до вимог ч. 2 ст. 171 КПК України [5, с. 68].

На нашу думку, основою процесуального статусу третьої особи, щодо майна якої вирішується питання про арешт, є такі елементи, як права, обов'язки та процесуальна відповідальність. Отже, першим структурним елементом процесуального статусу третьої особи, щодо майна якої вирішується питання про арешт, є їі права. Згідно з ч. 3 ст. $64^{2}$ КПК України третя особа має права, передбачені цим Кодексом для підозрюваного, обвинуваченого, у частині, що стосується арешту майна. Така правова позиція простежується й у судовій практиці (наприклад, ухвала Вищого антикорупційного суду України від 09.10.2019 р. у справі № 760/25192/19, а також низка інших ухвал судів перших інстанцій) [6].

Водночас зміст ч. 3 ст. $64^{2}$ КПК України не розкриває, які саме права належать третій особі, що свідчить про юридичну недосконалість процесуального статусу третьої особи. Так, невиправданим $€$ наділення третьої особи правами підозрюваного, обвинуваченого, оскільки останні згідно із законом можуть відмовитися від надання будь-яких показань. Це, у свою чергу, шкодить розслідуванню в ситуаціях, у яких особа, тобто свідок, якій відомі або можуть бути відомі обставини, що підлягають установленню, є також і третьою особою, а відповідно до КПК України вона користується правами підозрюваного чи обвинуваченого. Отже, порядок допиту третьої особи не врегульовано, оскільки у разі наявності в неї прав, передбачених законом для підозрюваного, обвинуваченого, й одночасно необхідності допиту як свідка таку особу слідчий, прокурор не має права під час допиту попереджати про кримінальну відповідальність за статтями 384, 385 КК України. Більше того, особа має право відмовитися від надання показань із приводу походження такого майна [7]. Н.М. Сенченко досить вдало зауважив, що особа в кримінальному процесі не може одночасно бути підозрюваним, свідком чи третьою особою. Неузгодженості щодо процесуального статусу можуть спричинити і відповідні труднощі в процесі накладення арешту на майно, що в подальшому може стати підставою визнання судом отриманих доказів за участю третіх осіб недопустимими [8, с. 72].

На думку В.І. Медведєва, під час регламентації процесуального статусу третьої особи, щодо майна якої вирішується питання про арешт, законодавець цілеспрямовано використовує досить складні прийоми нормотворчої техніки - поступово спрямовує до загального переліку прав і обов'язків підозрюваного, обвинуваченого та лімітує сферу їх здійснення лише арештом майна як заходом забезпечення кримінального провадження. Неординарність та деяка проблемність останніх виявляється передусім у ризиковості (алеаторності) їх застосування, оскільки халатна і неретельна екстраполяція окремих елементів одного режиму праворегулювання на інший може призвести до змістовних колізій, а також втрати 
специфічності предмета через екстрапольований режим [9, с. 384].

На думку О.Ю. Татарова та Л.М. Демидової, ще однією проблемою в кримінальному провадженні є момент набуття і визначення процесуального статусу третьої особи, щодо майна якої вирішується питання про арешт, оскільки такий момент, відповідно до ч. 2 ст. $64^{2}$ КПК України, виникає після звернення прокурора до суду із клопотанням про арешт майна. Залишається відкритим питання статусу такої особи у разі відмови в арешті майна чи повернення судом клопотання сторони обвинувачення з підстав невідповідності клопотання вимогам закону. За таких умов особа, яка набула прав підозрюваного, обвинуваченого, не може бути допитана як свідок. Загальновідомо, що в кримінальному провадженні статус особи повинен бути чітко визначеним [7; 10, с. 175].

Серед науковців також точаться дискусії щодо віднесення третьої особи до категорії інших учасників кримінального провадження. Так, на думку I.B. Гловюк, дії третьої особи, щодо майна якої вирішується питання про арешт, можуть спрямовуватися на: заперечення набуття майна від підозрюваного, обвинуваченого, особи, яка переслідується за вчинення суспільно небезпечного діяння у віці, з якого не настає кримінальна відповідальність, або перебуває в стані неосудності, чи від іншої особи безоплатно, за ринкову ціну або за ціну, вищу чи нижчу ринкової вартості, і заперечення припущень, що вона знала або повинна була і могла знати, що таке майно відповідає будьякій з ознак, зазначених у пп. 1-4 ч. 1 ст. $96^{2}$ КК України; заперечення вчинення підозрюваним, обвинуваченим злочинів, передбачених ч. 1 ст. $96^{1}$ КК України. Зазначене свідчить про захисний напрям дій третьої особи, щодо майна якої вирішується питання про арешт. Твердження, що третя особа, щодо майна якої вирішується питання про арешт, може бути віднесена до сторони захисту, грунтуються на визначених у КПК України формулюваннях, які мають відсильний характер прав та обов'язків цієї особи до прав та обов'язків підозрюваного, обвинуваченого в частині, що стосується арешту майна. Таким чином, суб'єктний склад сторони захисту має бути розширений шляхом включення до неї третьої особи, щодо майна якої вирішується питання про арешт, яка є суб'єктом кримінально-процесуальної функції захисту [11].

Зазначимо також, що законодавець, визнаючи третю особу учасником судового провадження, не передбачає порядок залучання її в судове провадження, крім випадків розгляду клопотання про арешт майна, не передбачає обов'язковий виклик третьої особи в судове засідання та наслідки її неявки, тощо. Наприклад, у ч. 2 ст. 314 КПК України вона не зазначена як учасник під- готовчого судового засідання, у ч. 2 ст. 318 КПК передбачено, що судовий розгляд здійснюється в судовому засіданні з обов'язковою участю сторін кримінального провадження, крім випадків, передбачених КПК, і в судове засідання викликаються потерпілий та інші учасники кримінального провадження. Проте надалі, у контексті наслідків неприбуття, оголошення складу суду й роз'яснення права відводу, дослідження доказів, виступу в судових дебатах участі третьої особи вже не передбачено. Крім того, відповідно до ч. 4 ст. $96^{2}$ КК України відомості про третю особу повинні бути встановлені в судовому порядку на підставі достатності доказів. Згідно з ч. 10 ст. 100 КПК України застосування спеціальної конфіскації здійснюється лише після доведення в судовому порядку стороною обвинувачення, що власник (законний володілець) грошей, цінностей та іншого майна знав про їх незаконне походження та/або використання.

Незрозумілою також є логіка законодавця щодо виокремлення в ч. 3 ст. 171 КПК України норми про арешт майна третіх осіб для відшкодування шкоди, завданої кримінальним правопорушенням, оскільки відповідно до ч. 6 ст. 170 КПК України виникнення процесуального статусу третьої особи пов'язано з клопотанням лише прокурора, але не цивільного позивача. Здається, що законодавець сам собі суперечить. На нашу думку, з метою однозначного тлумачення норм КПК України щодо залучення третіх осіб у кримінальне провадження необхідно вилучити з ч. 3 ст. 171 КПК України слова «третіх осіб».

Наступним структурним елементом процесуального статусу третьої особи, щодо майна якої вирішується питання про арешт, є її обов'язки, які визначено в ч. 7 ст. $64^{2}$ КПК України. Зазначимо, що цей перелік обов'язків не є повним, оскільки, враховуючи, що третя особа, щодо майна якої вирішується питання про арешт, має обов'язки, передбачені цим Кодексом для підозрюваного та обвинуваченого, у частині, що стосуються арешту майна, відповідно до ст. 42 КПК України вона має обов'язки, визначені також пп. 2, 3 ч. 7 указаної статті.

Вважаємо також досить суперечливим і п. 1 ч. 7 ст. $64^{2}$ КПК України, відповідно до якого третя особа, щодо майна якої вирішується питання про арешт, та її представник зобов'язані прибути за викликом до прокурора, суду. Проте досудове розслідування здебільшого провадить слідчий. Отже, не зрозуміло, чому законодавець не передбачив обов'язок третьої особи без зволікань з'являтися за викликом до слідчого. Зважаючи на викладене, а також із метою чіткого визначення обов'язків третьої особи та однозначного їх тлумачення виникає необхідність їх удосконалити та уніфікувати. 
Ще одним структурним елементом процесуального статусу третьої особи, щодо майна якої вирішується питання про арешт, є її кримінальна процесуальна відповідальність, що є важливим важелем впливу на будь-якого учасника кримінального провадження, спонукає до виконання ним передбачених законом обов'язків, забезпечення процесуальної дисципліни, неухильного виконання приписів кримінального процесуального законодавства України.

Отже, порушення третьою особою норм кримінального процесуального права, невиконання встановлених процесуальних обов'язків утворюють кримінальне процесуальне правопорушення. Механізм реалізації того чи іншого заходу кримінальної процесуальної відповідальності передбачає точне встановлення самого факту процесуального правопорушення, установлення правильної його юридичної кваліфікації, належний вибір індивідуального заходу примусового впливу, оформлення правозастосовного акта і приведення його до виконання. Вважаємо, що відповідно до статей 144-146 КПК України до третьої особи, яка без поважних причин не виконує обов'язку прибувати за викликом до слідчого, прокурора, суду, може застосовуватися такий захід забезпечення кримінального провадження, як накладення грошового стягнення.

На підставі вищезазначеного вважаємо, що у кримінальному процесуальному законодавстві України доцільно чітко визначити поняття арешту майна третьої особи. Слід визнати, що третя особа, щодо майна якої вирішується питання про арешт, має свій майновий інтерес у кримінальному провадженні, а тому не може належати до категорії «інші учасники кримінального провадження». Зазвичай до такої категорії суб'єктів відносять спеціаліста, експерта, перекладача, свідка, тобто осіб, які ініціативно сприяють у виявленні й розкритті кримінального правопорушення, надають допомогу особам, які здійснюють кримінальне провадження, тощо, але не мають власного інтересу в кримінальному провадженні. У зв'язку з цим доцільно віднести третю особу до сторони захисту. Для реалізації такої норми пропонуємо в § 3 КПК України (Сторона захисту) передбачити статтю $54^{1}$ «Третя особа, щодо майна якої вирішується питання про арешт», при цьому статтю $64^{2}$ КПК слід виключити з КПК України.

Пропонується також удосконалити норми КПК України, що регулюють залучення третьої особи, майно якої арештоване, до участі в судовому провадженні, судових дебатах, їі відповідальності за невиконання передбачених законом обов'язків. Так, вважаємо за необхідне перше речення ч. 2 ст. 314 КПК України викласти в такій редакції: «Підготовче судове засідання відбувається за участю прокурора, обвинуваченого, захисника, потерпілого, його представника та законного представника, цивільного позивача, його представника та законного представника, цивільного відповідача та його представника, представника юридичної особи, щодо якої здійснюється провадження, третьої особи, майно якої арештоване, та ïi представника, згідно з правилами, передбаченими цим Кодексом для судового розгляду» .

3 метою чіткого визначення процесуальної відповідальності третьої особи в разі неприбуття в судове засідання пропонуємо ч. 2 ст. 326 КПК України викласти в такій редакції: «Якщо в судове засідання не прибув за викликом цивільний відповідач, який не є обвинуваченим, або його представник, третя особа, майно якої арештоване, iï представник, суд, заслухавши думку учасників судового провадження, залежно від того, чи можливо за відсутності зазначених осіб з'ясувати обставини, що стосуються цивільного позову, арешту майна, вирішує питання про проведення судового розгляду без них або про відкладення судового розгляду. Суд має право накласти грошове стягнення на цивільного відповідача, третю особу в порядку, передбаченому главою 12 цього Кодексу».

\section{Jimepamypa}

1. Верхогляд-Герасименко О.В. До питання накладення арешту на майно третіх осіб у кримінальному провадженні. Вісник крилінального судочинства. № 1. 2017. С. 20-27.

2. Ухвала Апеляційного суду Одеської області від 30.03 .2016 р. у справі $495 / 1701 / 16-\kappa$. URL: http://reyestr.court.gov.ua/Review/689 15094

3. Музиченко Т.О. Апеляційне оскарження ухвал слідчого судді щодо правомірності обмеження права власності особи у досудовому розслідуванні: дис. ... канд. юрид. наук. К., 2018. 326 с.

4. Юридична енциклопедія: в 6 т. / редкол.: Ю.С. Шемшученко (голова редкол.) та ін. Київ: Укр. енцикл., 2003. Т. 5: П-С. 736 с.

5. Галаган B.I., Калачова О.М. Встановлення процесуального статусу окремих осіб, які беруть участь у досудовому провадженні: монографія. Луганськ: СПД Рєзніков В. С., 2012. 212 с.

6. Байдак Ж..В., Веселов М.Ю. Правовий статус третьої особи, щодо майна якої вирішується питання про арешт в кримінальному провадженні Wielokierunkowosc Jako Gwarancja Postpu Naukowego. 2020. Tom 1. C. 101-103. URL: https://ojs.ukrlogos. in.ua/index.php/logos/article/view/834/853

7. Татаров 0. Загрози при накладенні арешту на майно третіх осіб. URL: http://blog.liga.net/user/ otatarov/article/21968.aspx

8. Сенченко Н.М. Окремі питання процесуального статусу третьої особи, щодо майна якої вирішується питання про арешт у кримінальному провадженні / H. M. Сенченко / Ukraine-EU. Innovations in Education, Technology, Business and Law: collection of international scientific papers. Chernihiv: CNUT, 2018. P. 70-73.

9. Медвєдєв B.I. Окремі проблеми практики застосування арешту майна. Юридичний науковий електронний журнал. № 6/2019. С. 384-387.

10. Демидова Л. М. Питання спеціальної конфіскації майна третіх осіб. Порівняльно аналітичне право. 2016. № 3. С. 174-176. 
11. Гловюк I.В. Третя особа, щодо майна якої вирішується питання про арешт, як учасник кримінального провадження: проблемні питання. URL: https://barristers.org.ua/news/tretya-osobashhodo-majna-yakoyi-vyrishuyetsya-pytannya-proaresht-yak-uchasnyk-kryminalnogo-provadzhennyaproblemni-pytannya/

\section{Анотація}

Назаров В. В., Слалюк Т. В. Особливості нормативного регулювання процесуального статусу третьої особи, щодо майна якої вирішується питання про арешт. - Стаття.

У статті на основі аналізу кримінального процесуального законодавства України та практики його застосування, наукових праць вітчизняних учених, узагальнення емпіричних даних комплексно досліджено процесуальний статус третьої особи, щодо майна якої вирішується питання про арешт, їі роль у кримінальному провадженні, процесуальна регламентація арешту майна такої особи та забезпечення ï прав і законних інтересів. Проаналізовано такі елементи процесуального статусу третьої особи, як: права, обов'язки і процесуальна відповідальність. Доведено, що третя особа, щодо майна якої вирішується питання про арешт, має свій майновий інтерес у кримінальному провадженні, а тому вона не може належати до категорії «інші учасники кримінального провадження». У зв'язку з цим запропоновано класифікувати третю особу як сторону захисту.

Установлено, що можливість накладення арешту на майно третьої особи зумовлена необхідністю реалізації публічно-правової мети кримінального провадження, а саме спеціальної конфіскації. Доведено, що під час реалізації цього заходу третя особа обмежується у праві власності на своє майно, але не втрачає права на нього до винесення остаточного рішення судом, який i визначає кінцеву долю арештованого майна. Прийняття слідчим, прокурором, слідчим суддею, судом рішення про арешт майна третіх осіб має підкріплюватися даними, що вказують на важливість його застосування через наявність високого ступеня ймовірності приховування, пошкодження, псування, знищення, перетворення, відчуження відповідного майна.

Обгрунтовано позицію щодо вдосконалення положень чинного кримінального процесуального законодавства України, які регламентують процесуальний статус третьої особи, щодо майна якої вирішується питання про арешт, порядок залучення іï до участі в судовому провадженні, її відповідальності за невиконання передбачених законом обов'язків.
Ключові слова: кримінальне провадження, третя особа, щодо майна якої вирішується питання про арешт, спеціальна конфіскація, сторона обвинувачення.

\section{Summary}

Nazarov V. V., Smalyuk T. V. Peculiarities of regulatory regulation of the procedural status of a third party with regard to the property of which the issue of arrest is being resolved. - Article.

In the article on the basis of the analysis of the criminal procedural legislation of Ukraine and practice of its application, scientific works of domestic scientists, generalization of empirical data the procedural status of the third person concerning whose property the question of arrest, its role in criminal proceedings, procedural regulation of seizure of property of such person and ensuring its rights and legitimate interests. Elements of the procedural status of a third party are analyzed, such as: rights, duties and procedural responsibility. It has been proved that a third party, whose property is being seized, has a property interest in the criminal proceedings and therefore cannot belong to the category of "other participants in the criminal proceedings". It is therefore proposed to classify a third party as a party to the defense.

It is established that the possibility of seizing the property of a third party is due to the need to implement the public law purpose of criminal proceedings, namely special confiscation. It is proved that during the implementation of this measure the third person is limited in the right of ownership of his property, but does not lose the right to it until the final decision of the court, which determines the final fate of the seized property. The decision of the investigator, prosecutor, investigating judge, court to seize the property of third parties should be supported by data indicating the importance of its use due to the high probability of concealment, damage, damage, destruction, transformation, alienation of relevant property.

The position on improving the provisions of the current criminal procedure legislation of Ukraine, which regulate the procedural status of a third party, whose property is subject to arrest, the procedure for involving her in court proceedings, her liability for failure to comply with statutory obligations.

Key words: criminal proceedings, seizure of property, third person in respect of whose property the issue of seizure is being resolved, special confiscation, prosecution. 